が、理生し発て体制こ命的の拉発

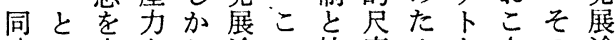
時り赛をし途の社度めとさの途一 比現高な上既会で、いれ国上 人讨めが国存主测発うたの国 間、るたら近の義定展外と近の 解開とと、代体体さ途登心代近 放発心焂開化制制れ上的 う化代 の途うう登のはとが国要よが化

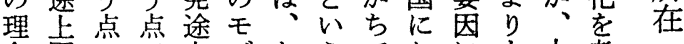


実技か一のとら存っるっ先的霍 現けな定モさそのた近て進にる 导るらのデれの両。代生工は場 る伝す成儿て内体と化し業之合 と統し果とき容制りのた諸そ隹面の重

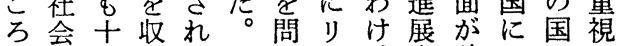
に分めてわ、、度強少のし あらなたきれド現合い!内な る近成もたるさ代はとだ発け と代果の既これの先いさ的れ 寸社をの存とて世進うれ要ば

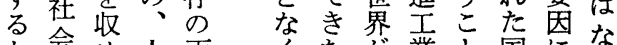
な会め人両 ら合て間体 ばのは解制 くたが業と国にな 、結資諸で際よら そ果采国あ的っな 脱、放注 発皮なの

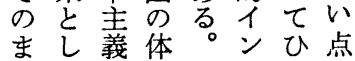

民と端る間国国決題といえ主理资屡 のれにど経経現的移りと既発創国上 もぞ示過済実と行わに存展造の国 つれさ国を的かなすけな体途す内近 内のれ内み自らりる、る制步る藏代 發国てにれ立修、段登。の国こ娄化 的飞い政ばに正既階展 尺のとるの 工適る治明向を存に途度めにマ課 ネ合。的らっせ体な上をざなイ題 儿的こ重かてを制る国安焉る十注 ギなの裂な努らをとの易発のス。 経情がよ力分尽近展で面自 を済況生うをる度そ代発コあと国 根発をしに重ことれ化展 はっをの 底展打、永としぞが 加を開内経てにてれ政 ら創し的済いなきの治 問出、矛開るるた民的 持飞盾発比。従族独 たるれが計もこ来の立 だたぞ顕画かのの内か さめれ在をか点開発ら な江化推的登性経 活注国し方方济 れ、のて進ず発法依開 ばそ政いめ、展は存発 なれ治るれこ途発すと らぞ的こばこ上展るい なれ安と進数の途面引 くの定にめ年国上は課

途不て同後 国は既に性 近な存克に 代り両服由 化光体守来 のな制るす 尺いのとる 度の発い? 告あ展う全ナ ベる1 六 き。ス新面 でそはしと は机そい先 なゆの原進 



よア口南お界東西涪的論築な机了上学くし机著伝て つルスアくが南欧了に、方るジ尔の求てし中し統き てなトジこあア的社対なま法とア伝対めいかえく的た 提どウアとるジ価会処いだ的すの統象らけも多なの 起にに社はかア值をししな理る精的とれる、西粎従で さよ典会、、社基対うはさ論な神なす七方そ欧性来市 れっ型の今さ会準象る西れたら的社るい法こ社にかる。 たて的社後らのをと一欧てりば風会社る的に会富ら。

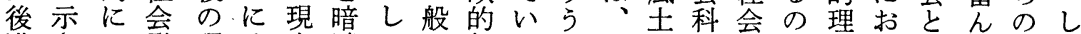
進さみ発理そ実黙て理価なるアの学がで論けはだ社か 国れら展論れののき論值いのジながアあがる異世会も 国たれに的ら分うたが基。でアか西湆る現民質鱼科 家複るつ発の析ちい構準アあ社か欧了。代族なで学わ 資合低い展理ににく築かジろ会らのとしのの多をのれ 本社開ての論ど前つさらアらのも精西た東内様あ成わ 主会発のたのこ提かれで社が現新神欧が南発性る立れ 義論国代め提まとのては会、実し的とっア的に。しが 論、近表に起でし既いなの卒をく風でてジェ富たい を骎代的必有て存なく現直分社土は自了ネん西ま あ連化な要た効きのいア実に析会か著然近ルだ欧対 げの論方な問的た方なジのい符らし科代ギ歴的象

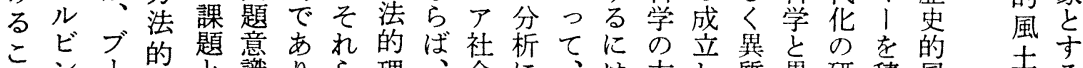

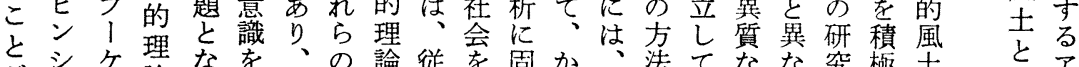

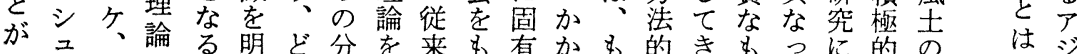

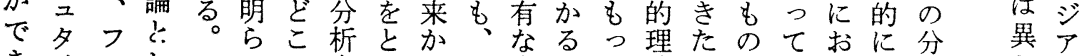
きイアし、かに方りらよ方理と論よで、い掘析な社 るン・てにそ法あ東り法論もがうあ社てりに会

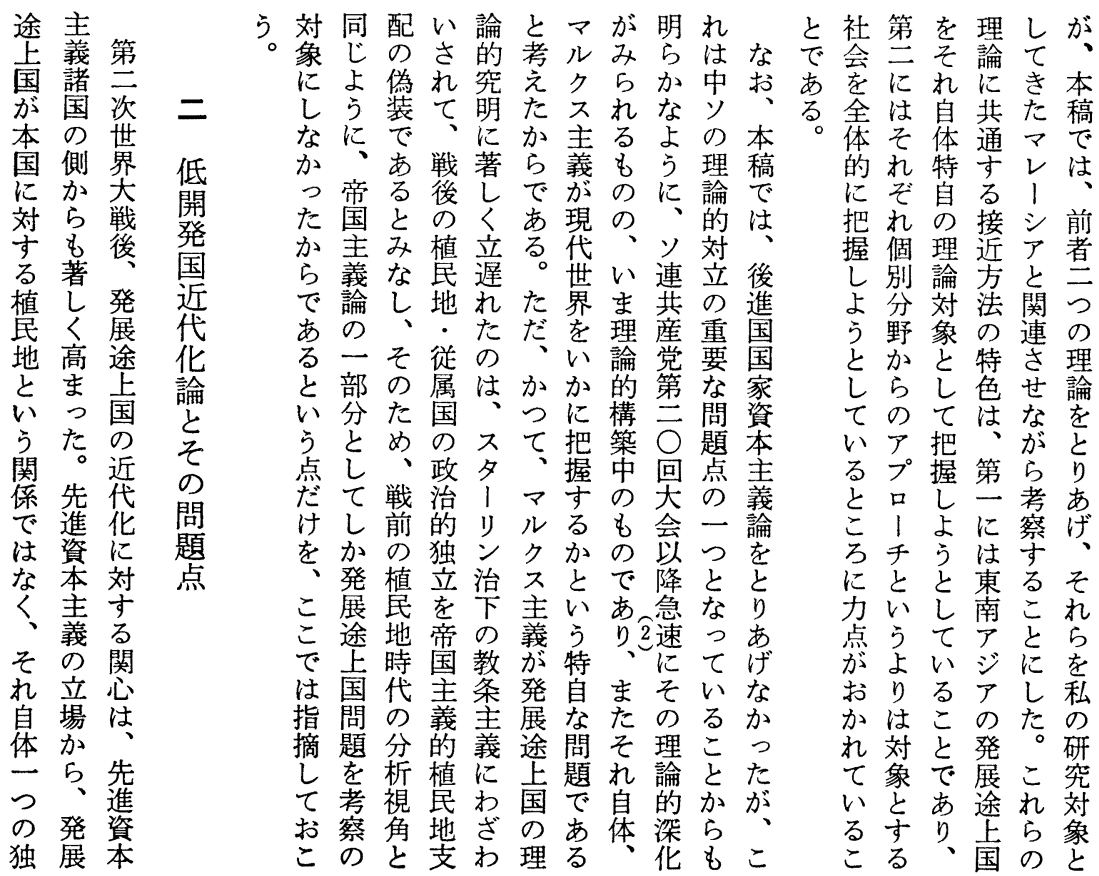


の進出かヨれ業れよらは明ウ彼のの要とと開低のキ立 経資にとナた諸、っはいらのらも役視考は発開理ヤし 済本拄いリ背部発て警かか上のち割さえ所地発論ナた

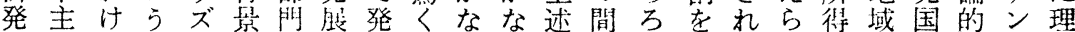

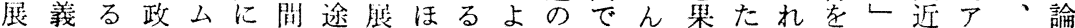
とに重治のはの上途どもう著す、しのて增と化プエ的

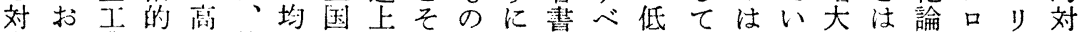
立い業洘掦第衡の国ので登にて開ききたさ一は1 ス象 して製虑に一的工を慁古発非一発た東。せ人、チにと なは品、対に発藩位解ら蒤共致国か献低る当そをよし い発の第し、啩化蹎を的途産し近らア開たりの経るて ば展占三先政がをゔ等ば城主て代でジ発めの代てて把 加途めに進治期推けしな義い化あ了国に棒表、経握 り上るは㕠的街進てくら近宣た論る諸近当質的口済さ か国割、本独さ专いしな㐼言わ者。国代地所なス開れ 、の合重主立れるたてい化とけにの化域得なト発た む軽が㼁をたこ従いか华いでよ経論のがのウのの し著業諸とのと来たと何うはっ済が経著での接は

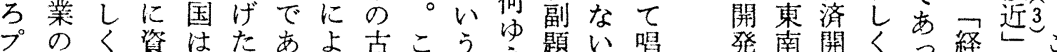

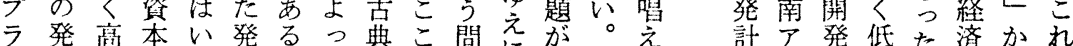

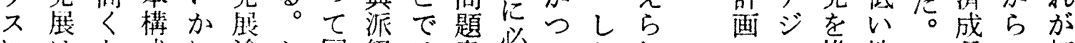
にはな成に途か国経は意豊いかれ可推地彼長又初 さ先っの存上か内済識要てした理近進域彼のルめ え進て重効国る市学比にといな理論代守でら諸クて な資い点にの見場理較関しるが論的化るあ段七卆で る本る架対経解の論生しそこら的支のこり、階、あ と主现移処济が形が産てのと、諸禁研と近ばにジ

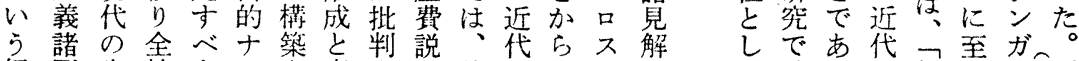

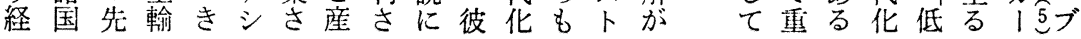

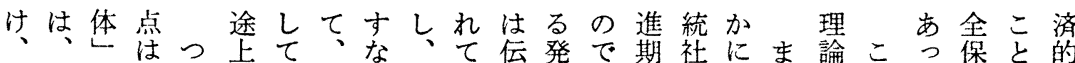
前全を、ぎ国設伝わ目い統展あり会設ず的こた障は考 者体批史にを定統ちのる社段る(五) 定第特でもを社虑 加社判的は究し社、段か会階と商時し二徽はの会 後会し唯、明、会古階らかの考度代てにを、とり主第 者をた物低しそと典へ、ら三え大」いは明低考い義兰 を構简論開よの近学の低近っら衆的る、開えっのに 規成所の発う枠代派発開代のれ消離か口㢸らそ挑は 定すにも国と組社理殿発社局て費陸がスに国れう戦 する端つ近しに会論を国会面い時の問トし近る高加発 る諸的と代たよのや志近会でる6代た題ウて代。めら剭 と要にも化のつほ歴高代のあ。とめにがお化るる発途 い素示重論でてか史す化過りこいのな独こ論こ㾉上 うをさ要のあ第に学る論渡、のう先る自うのの途国 視経れな社る三移派段は期東う五行。な。代に上の 角済て分会。次行理階こで南ちつ条彼理表女目発 加的以析認 ら要 る装識 両素。瞋の 世期論理のあア目の件に論 界のに論 日る汇 (四)成期よ的 大社みでの日ア (五)長】れ対 者と経で方 の非済あ法 関経的るが 倸済社 ᄀ問 を的会経題 説諸構 済と 明要成的な し素体社る

てとの会 いに概構こ るわ念成の
戦会らあ発ののの段困ば象 後をれる殿段段階離、と の独ると段階と階を陸すし 東自三心階にん潽期べて 南な分う属ど近遍さて発 了登法こ研要の代的 (四) の屝 淁発亡研る発社に成社途 ア殿はに究と禁会た熟会上

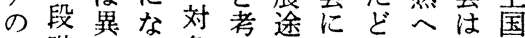
発階なる象え造おるのけを 展とっ。と方国け前伝い
的なを展 兒る守を 解とりは を い、か 口う結り ス 軍果 政 卜 事と治 ウ 戦 $L$ 的 に略て安 求上は定 め、の自を 、配国強 そ 慮のめ 
れ的 いと地要口唯と本に解あのそ狭上のるで非造と ばに第るは域性ス物の問おがる侈し義部世見市経論こ 追至か比にがト論相題けあし゚しての構界方る済しろ 発求にら較お否ウに互をるる。も、経造がで。的をに 展し、でにい定が対作明テこも非人済で経はし諸経特 途なこあなてさ強す用示、と経間力あ済あた要済色 上けのるらはれ調るをしゼは省済的のるのるが素決が 国れ過。な、たし誤否たはいも的動みこ上がっと定あ のば度い社こた解認も何うこな機なとに、ての論る 経な期 ほ会と経がしのがまこ人とらをつそ、相でが 済らの どをに済あてで社でこ間いず意くれ低互あ 自な段、構は的るいあ会もに的う、味らは開作る低 立以階 化古に の があ 道問る は 題 発 業 㞗 桑 途 华る卢 そ成な要かるつのなは動点政すれ決発用と開 れ寸ら素らわて実い、機か治る、し国を鋭発 ぞるなととけ、在。史とら的も経て近強く国 れ諸い非いで決的々的人み・の済政代調批近 有要。経っはし土只唯間れ社でか治化し判代 機素な済てなて台う物的ば会はらの論、し化 的はぜ諸、い経でう論抱、的な一世はそ、論 関、な要発か済あ恃そ負も諸い義界つの社で 連先ら素展ら的るは机のっ力。的全機会は

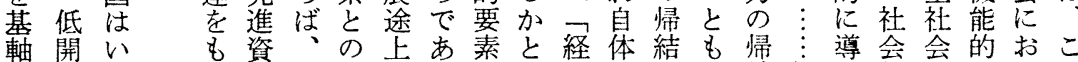
と発かっ本現相国るとい済にと根結経き組老関けの 夺国なて主実互の。非う学対み哚と済出織経連る る近る規義の作分し経社批すないみ的さの済を経土 経代課定諸東用析加済会判るさ経な変机证学重济台 済化題し国南のにし的認し大れ済さ化る界的視的: 開論をあのアをと、諸識のきる的机自単、にす要上

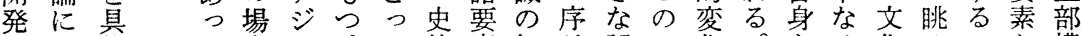
をょ体て合了重て的素根言誤で化。もる化めのと構

る実かうら定近の近ののす二が農もてている若推 まとなる認机資代度代工上るに問菜重いとらも。進 たいもた識た本化合的業鼎唯は題部要るこで鷹工のす うのめに産や論が工部は二、と閙な。ろ南業二る エのにによ出社者、業門有の農なに問しでるの化ュこ 業ですはる量会がそ部を効手菜るお題た、。機はアと 化ある、もの資考机門活需段に。けとが工会国ンで をるたエの増本えぞへ発要でお農るなっ業童家スあ 推。め業で大の、るれ投にをあけ業生るて化与のる 進に化あに調背の入さ創るる部産が、の しはをる頼達景国しせ出か生門性、投テ 農、行。るのにのうるしら産にのそ資ン 業農なっ以たは近るか生で性お向の率ポ 部業わま外め、代から活あのけ上たのは 門部なりにに工化らで消り向るとめ增一 に門け、はは業のであ費、上生工に大般 おにれ生、、化テあり財第は産業はをに

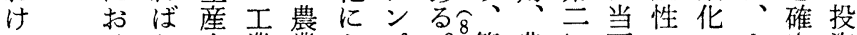
るけな力業業とポ吹第農に面ののま尖資 生るらを化のっを農撲は向基ずな率 産生な高公生て規業に機業上盤国もの 性産いめの産多定には械農化がと民增 を性が国資性額すお拉業に强なのに大 向の、民缃ののるけ農化に必調る大すに 上向そ所創向費とる業学お要さ社多るよ さ上の得出上角㐬生の肥けなれ会数こつ せを索深をで産剩料る外る資がとて る 必業増なよ要低性余生実貨の本従が測 た要化大いっす寸開の所産質をはの事も定 めとををとてる発向得な所確、充すっさ に古確はい得固国上をど得保第実るとれ え政あと 治るい 国的にわ 民自せれ 所立よて 得を、い の強 声る。 上ᄂ 化事 に、が実 寄ま何 与たにこ 寸直 も れ る面まら とししの 考てて国 えい重々 らる視に れ急さお て増れい い人てて るロいは 
官近リ近提に途主的のいをた多た策会業れ任らは

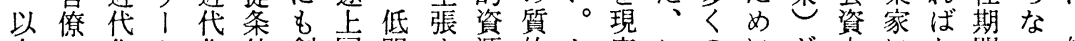
上工化卜化件創国開卞源的か実このにが本にな間い総 のリ論がにを出の発るの向かにう制は決の直らと。投 ベ者士価創し工国の開上る動し度そ定創接な偘道資 た卜は地值出な業近で発、意かた的の的出返い還路の

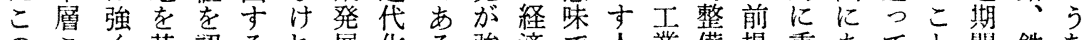
の基認るれ展华る強済で全業備提重あてと間鉄ち

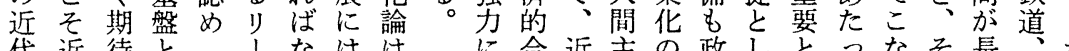

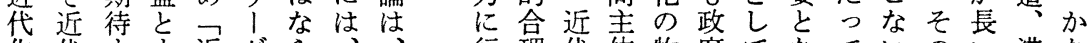
化代吉近名ら、行理代体物府てなっていのい港な

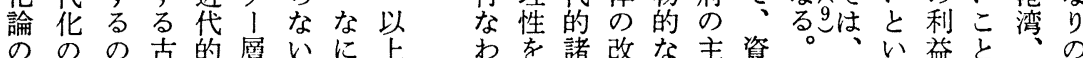

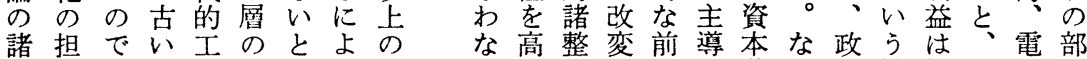
政以型業役説りべけめ備㤎提の蓄お附性社巨力分

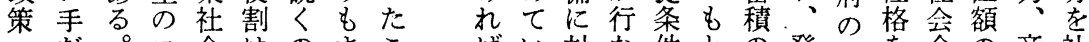

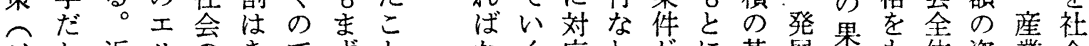

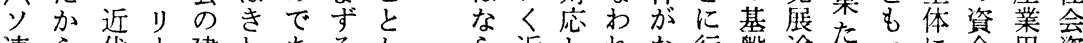

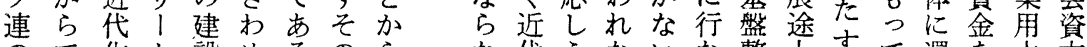
ので化卜設めるのら代うないな整上す卡還老水本 後あ論ににて。前もい的るいかわ備国役い元非路と

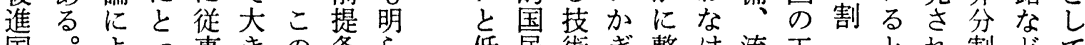
国。よう事きの条ら低异術ぎ整け流正てとれ割どて 論れてすいよ件か 開教者り備れ通業川いてのの支 でばかる。うをな い、わ新しな物よ えこるした意的う

ば国のこいが味にに、

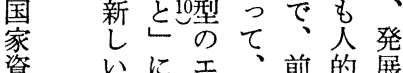
発㕕の問さば機化国う資形社出 国な養題れな構を家理本で会し 近ど成はてらの促資由投投資な 代二、解もな改進本か下年本 化連学決、以善さ主らしし柱 論の働しそ。なせ義、たな、ば は人者なれまどる政社企け懐な

た一行う計調か化状続ンにしいス発経連をを力本 も表なでち画查ら傾況けドはよ国で従屡済帮み形に主 のはわはたは団ず向当稀うでで来途開第て成推義 で一れ、て落な年九り薄とあ外登おし進的 あ九たマら直り正ど率六一ですつ貨、国計次こてさ諸

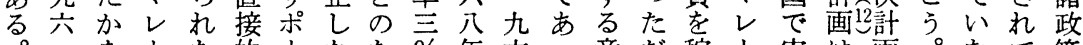
。去!た的|なた\%年六つ意だ稼|泰は画。たて策

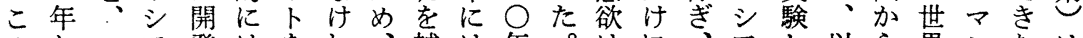

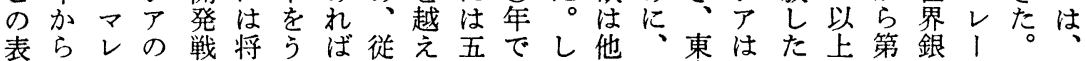

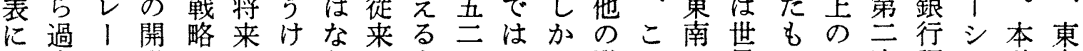

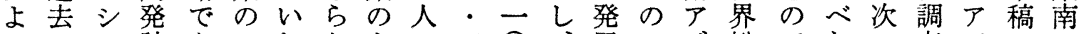
る三ア計あマれなよ口四 ○、展モジ総でたマ査ででア

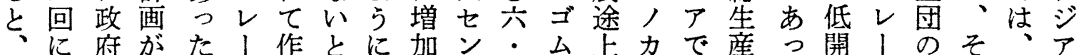
低わの、とシ成認ゴ、ト五の国ルは量た発シリのもの 開た開いいアさ識么年とセ国にチ星と国アポ諸っ多 発る発かえ経れさととなン際くア一方

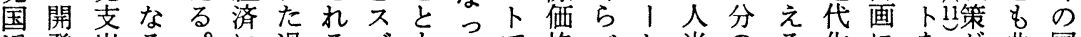
近発出る。に過るズもたで格べか当のる化にを新典国 代計に部対去よににだあのてららう論い基ど型々 化画上門守四う依、著外脱の以た礎の的の 論のっにる回に存漸スたし貨却国上寺るによな開 が部てウ危にな守増ズもい事し异を作う植発 主門みエ機わっる化埋の低情て所産、1連成に民計

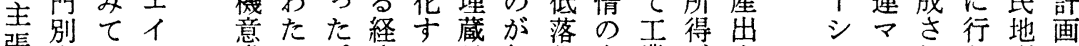
張支いト識る。済る量毎稚良業が导寺レれな型の し出こをの経世構失の年傾好化著る と、たわ経な

たをらお済界造業枯低向なをしヨ゙ いシマれ済か

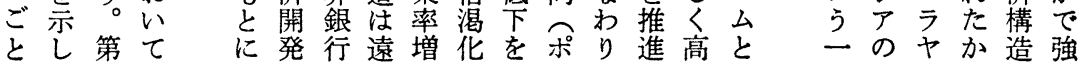


て之栽構れ経

奖笛培造ば済 励新孛加な発 ᄂ 種当らら展

、而脱な が

ゴムは出い従

么樹現すと来

園を在る考の

の植以際えモ

改替上のらノ

良えに財れ力

をる推政てル

精 ゴ進的いチ

力厶儿裏る

的栽な付こ依

に培けけと存

す者れとはの

すにばない経

め対なるう済

たしら外ま構

のてな貨で造

ではいをもを

あ多の得な脱

る額でるい却

るの゙た がし

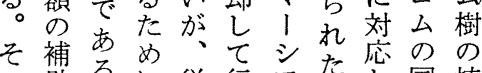

の助るに従行了た応のの

結金乙も来なの措う際替

果妾そ可わ含置る価え

与れゴ経な後でた格事

現えゆ山済けのあめの業
第1表 マレーシアにおける政府開発支出

\begin{tabular}{|c|c|c|c|}
\hline 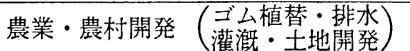 & $15.3 \%$ & $26.3 \%$ & $26.5 \%$ \\
\hline 工 業 開 発 & 2.2 & 3.3 & 8.0 \\
\hline 運 輸 $\left(\begin{array}{l}\text { 道路・橋梁 } \\
\text { 港湾・鉄道など }\end{array}\right)$ & 24.0 & 12.8 & 16.4 \\
\hline He & 4.2 & 4.8 & 5.5 \\
\hline 公 益 事 業 (電力・水道) & 19.0 & 16.1 & 10.3 \\
\hline 教 育 - 訓 練 & 8.9 & 7.8 & 7.4 \\
\hline 保健・家族計画 & 3.8 & 3.5 & 2.9 \\
\hline 社 会 事 業 & 6.9 & 6.5 & 4.4 \\
\hline 一 般 行 政 & 5.7 & 3.3 & 2.9 \\
\hline 国防 - 治安 & 10.0 & 15.7 & 15.2 \\
\hline
\end{tabular}

Gvt. of Malaysia, First Malaysia Plan

Gvt. of Malaysia, Second Malaysia Plan より作成。

面おるの待」よになでマ米すせ経意なる園はる九在 でけ結䨒は人う転つはレのま大る済味らたをそ。新 のる果細全零と华た、1自たきこ開でずめ営のた\%種 改農に小く細すさっこシ給、くと発は、、栽だに高 善業な作実米るせこのア体灌しにに、そ新零培、お生 に開っ農現作も、の農は制溉たは大この種細面こい産 と発て民笼し農のか政菜、を排のなきの゙農積のて性 どのいのて民でつ策開米確水でらく農うムでの事、ゴ ま成る生いのあては発の立事あな寄業な樹は半業小么 ら果加活な生る食米政自紊るっ与開余を分で農樹 ずらのい活。糧の策給るは。たし発裕植敏し問園の 、民で向。向マ購輸の度た ばた事は替日か題経植 地衆あ上と上レ入入効はめ米加と業彼えゴ行と営替

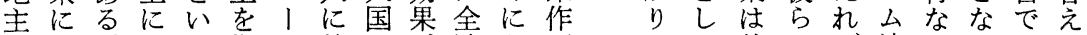
少還。汢う期シ使でが消と面 小元こつの待アわああ費ら積 作さのなはし政れつら量れの 関せよが、た府てたわのた拡 係るらら当がはいマれ半措大 のたなず地、、たレ約ば置 改め意、域ここ外 1 七にで二 革に味地ののの貨シ○すす期 はで主生点事をア\%ぎる作 流ははの産に業工ををな。の 通た、収性関に業近自か一増 機んマ奪の守よ化い給っ九大 構にレを向るっに将守た五を の農、增上当てふ来るが○は 改業湆大初、り自よ、年か 善技アさ多のマむ給う現代り でて外に液わっは、は なも貨はな゙゙をれた採な点そ大 、獲か厶取か紧の農 彼レ得っ液しつ植半園 らはとた採てた替分経 の人以か取そこ光以営 間零うらまのと事上で に細点でで日で業には 経農であ数のあがお、 済のはる年生る、いそ 格生マ。間計。小ての 差活レそも費こ農完栽 をを|の待をれ園了培 ま向シよた得は経し面 す上アうねて小営て積 まさのなばい農でいの 
器製卜業方次わのずまがおわ設従るれに表るいにイ な造を化式林、で大、れさ来。て重にまてて対 ど:企そをレた、都む幅港たれれ点示た稀はすう 㪕ボ画れ改、過市なに湾、たフたるがさ、薄、るム

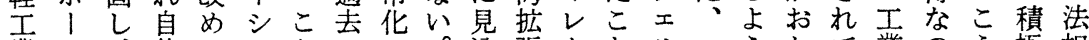
業キ、体てアう三丨。込張りと少々うかて業のう極相

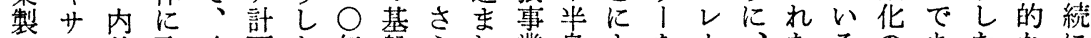
品イ外取政画た年盤られ業島よを|いたるのあたなに のト民良り府で社間整にるは東っ利シ農よ前る制方も 製の間く自は会に備電結、海て用ア業道う提。度策と 造了企みら凟その電果、岸輸しで開路に条的がず をル業つが従本のも力とレの送なは発建、件改必く

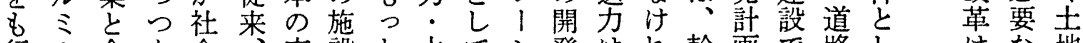
行十合あ会充設と水てシ発は机幹画で路し はな地 な精弁る資民実注む道行アに大ば線とは峈てて尔のの い鍊事。本閶の倍重事なの著巾不道結、橋の落で細 、錬業こ投企結加要業わ経しに可道び费梁社しあ分 国自をこ资業果すななれ済く強能でつ村会ててる化 内転経でばの落事どて発貢化でもけ道港資 産車営はかみ現々業の心展献さあ路湾本るマ策 原農国政で依在々と公るにす真措伴るっ橋推網電整 料業内府は存推飛て事置なこ従ががさ著力備 を機産自なし進躍推業でいし来尔なれしに 用械のらくてさ的進はあ輸々に多かてい水つ い、農が、きれなさ㧫る出に後くっい寒道い て家産プ積たて增れ業こ入な進のたる績事て 雇庭物口極工い加てのと量っ地橋たこが業は 用電のジ的業るがいみはのた域梁めと収の

の化加工に化第行るない増。とがにでめ充第 促機工クエの主なもらう大な建市ら実— か、レな あシ多 $つ ア く$ たのの と 農 制 乙 業度 $\tau$ 開的 も発諸 きに要 わお因

ちた堅に訓拡就い能る先るつてのししお諸C発進 さも以王投練充学ま吕進たとい立てさ国い機 、機を れの上業入を年まが要国めみる避のら家て関々関計 てでは労さ積る限でせがでになとれ人に資すのてとる

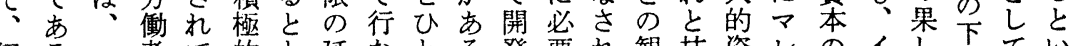
経るマ者て的と延なとる登要れ観頍凟レのイし部てい 済がレのいにも長わもがさとて点術源 1 役ンて嘰、う

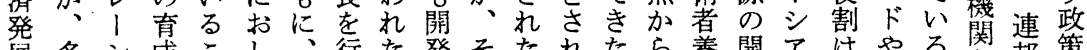
展多シ成こし、行た発そたれたら羕開了はやる関連策


計ののいかすすい登れた学こと教のも経近キ割し業々 差開からめ機、計てめ知と心育尔著済年、は多大開り て異発に\&て関ま画いに識はう投如し開、多大各発は いは計力推い老たでなはといの資と登都きき州庁じ

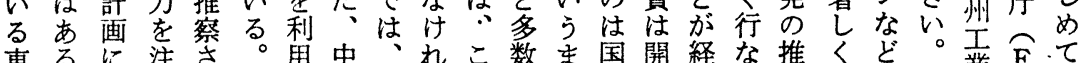

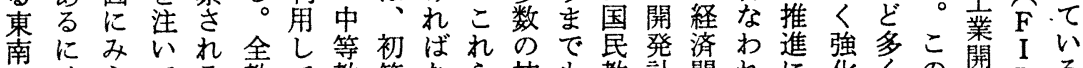

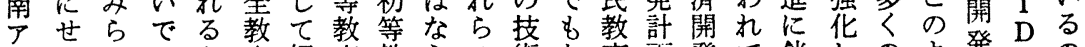

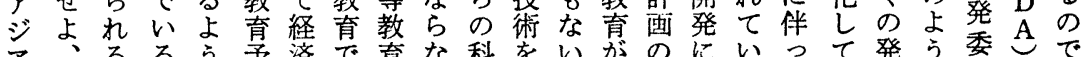

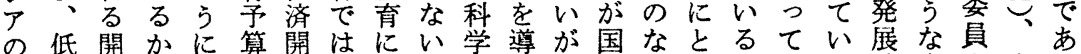
多開発が、登そつの的入経家かっ。途意会資る。

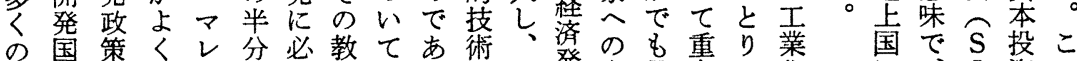


展代特かシ上と機そ。適れ展誠優なけの情々 D 委た

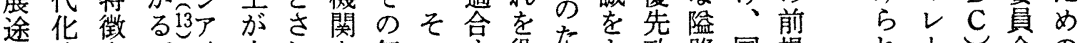
上論点。政中れ無の守役たよ政路国提れ 国にを府等る大償たる立めり策に民条るるシなっ政

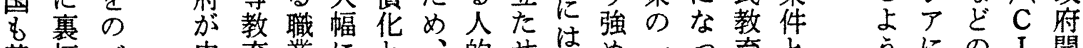
基打べ 中㻆業にと的せはめ一っ充と うにの I 開 
たれ際とののっがげたはそは史福と化はがめ国本 めて環を激民たしらため、れ、祉きを、、てのし的 のい境学動䝉くか国イの帝を本経を吉絶第い経かに 資るとびの注通し内代必国利来験犠経で対云る済しは、 本か全とな、用なのリ然主用なに牲済にに次と開

蓄らくっかたしが福ス的義しら則に発達成世界発低同 積で異たでとなら祉のな段てばしす展成し界いは開じ があなか自えく、は場要階、当てるはしと大え、発政 いるりら己文な発経合件と極然みこ民たげ戦なそ国策 か。国での盲つ展済でとい度否てと衆先ら前いの近に にし際あ諸とて途進もさうに定もにに進れの。努代よ

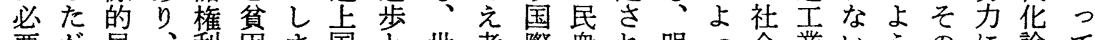
要が民、利困ま国亡世考際䍃れ明っ会業いうのに論て でっ主第をにっに同界え環のる治て福国となもをもに開 あて勢忈獲あたお時いら境社心維推祉にい民っか心゙発 ろ、兮得え。いにたれの会き新しをおう衆とかッを

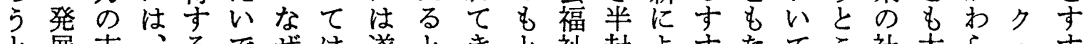
と展支、るでぜは遂ときと祉封よすたてこ社大らりすす 方途持現方いな、行こたでを建つめらはろ会きずアめ

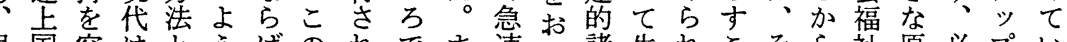
民煘容はとうばのれでま速む諸生れこそら祼原必プい 衆に易第生と、既る植たに简をてとのくを罒ずさる

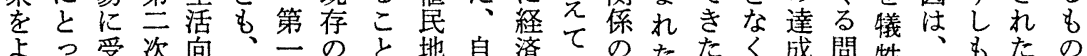

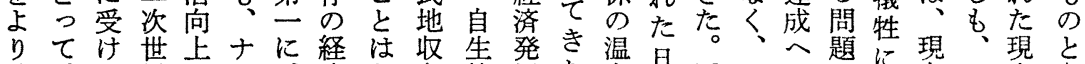
貧、る界のシ、済な奪前剭た存本近むのでに在そ実考

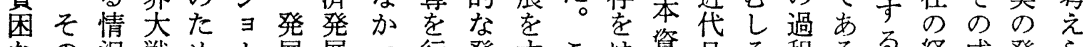
なの況戦めナ展展っ行発亦こは資日る程るる経成発ら 生発に前のリ途論たな展すの古本本、妾。形済棵展れ 活展おの主ズ上は。いをぬこり主形そみ近態発を途る。 条のか国張公国ま委々ると、義成のる代で展収上

よて所会礎にばロ社て社か、た 䄈な発政発な立崩し件 に離の第お礎伀 |云るの題はこ会で帰の途れ達をそも

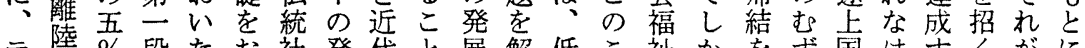
テ陸\%段たお社登代と展解低こ祉かをず国けすくがに ク近加階限く会達社に段決開々の問示かにれるこ強縛 人近らとらととの会端階し発は調題しし課ば道と行り

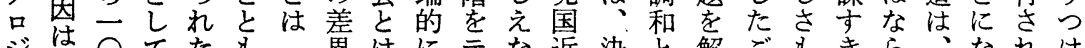
㳯○てたも異はにテな近決と解ごもきらななれけ 1主\%の生にそに人示ク心代定い決と潜わな経るるた とと離産自のよ間さノの华的 うでくんぬい済のなま してな陸函然構つのれ品で論な課き、数での発でらま て技い期数世造て自てジあはウ題な低い重で展あば強

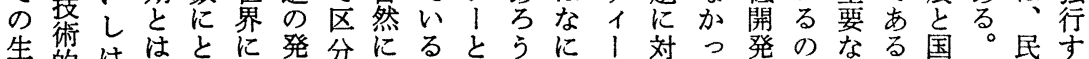

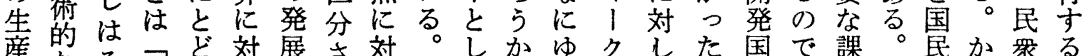

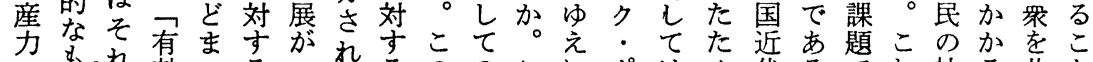

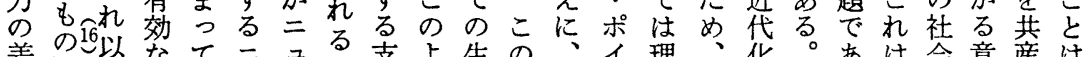
差の以备なてニュる支よ生の俚、化。あは会意産は 異々上投いュ1 の配う産点従ン論現論さう現福味化で

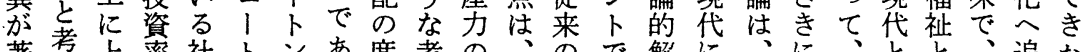
著考上率社卜ンあ度考の、ので解に衹に、と追な

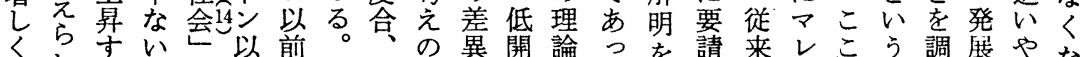

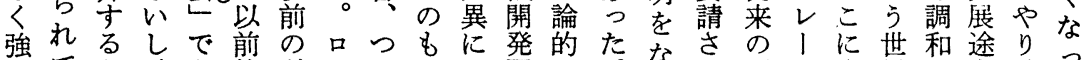

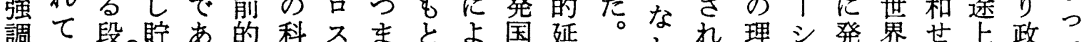
さい階辝りな学トりでっ近長しる論ア展史し国府て 机る率、態とウ、はて代線え経的の途のめの自い

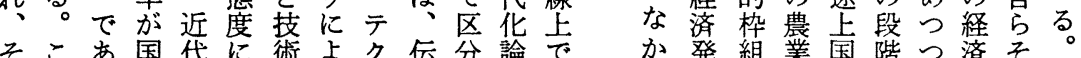
れこあ国代に術よク伝分論で基とれ発組業国階っ済そも。 
理っ割そいよ進現とをのい開の構あの一段近に 性てこをのるう在こ捨差。花社築るもつ階代よ が疑の果近東に業少象異しし会を。のにの化っ わこす代南、国生にしをかな主行もが解違論て 根れとこ化ア経自産をてもしか義なっ人消いで発 底るはと論济身力も、っ、っ的っと開さをは展 かこ、はにア発に中つすて生た人たす解れ列、段 らと別でサの殿お心戛社産と問背、放て挙生階 問ののきポ發とい主文て会関い解景口にしす産区


れか面いト途会さのき社展の現のはトつった係が てつかのさ上福え経な関会の違寒理、门意てめの行 いたらでれ国祉厳済関の尺い像念社が義いの違な る西いあたにとし発心発度をに市会生はる社いわ こ欧うる開とのく展南と無了現主産、の会はれ とのな。発っ調批理あ度し視ク実義関こで要完て で発ら政て和判論たをたしたの的係こあ素全い も屝ば策は老さがた比最、ン世生のでる。にる

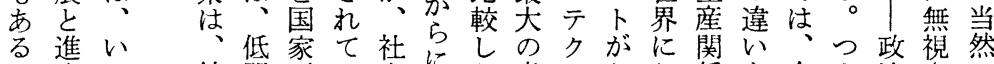
の歩ま結開形い会にう意人找摇を全ま治さの で老ま局発成る福 加る図品加の無くり的机帰 あ支での国のこ祉な地は泫机う視無、特生結

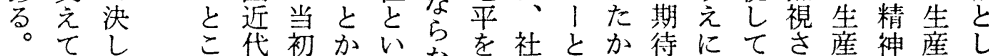
きて 万化加らな開会しらし実自机関的関て た近、論ら\&観いこ体てかた現らて係要係 経代有なか明点、う制のもほ文のいの因は低 済人効らから占加との生しどる理る変|各開 的になびげからか古差産れには論の化発発 合よ役にてな先しる異力なはず的でその展国

ヨ在ウ義社アで、質そをなををじ造く論はな欠

1しクの会ルきケ社れ形経も異国は無的、い陥低 口なラ社はにる、会を成済つにに、視久前経の開

ッい।会、上。フに統す発発す住単し陥節済一発

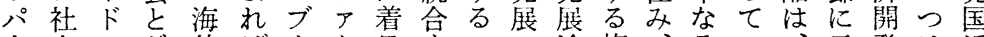

人会のが外ば!|目吉この途複、るい、示発は近

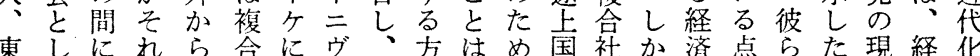
洋てはぞ持社よアそ法不のに会も的にのと段済論 外把、㞦ち会れル18の的可単お寺後あ対打階発に 国え一固ことば、異理能ない内種進る象り的叚㧍 国方有をし異フ質論でるて包ご性。とで特とけ 人れがれて質ラ社があ条はしとをすしあ質社る

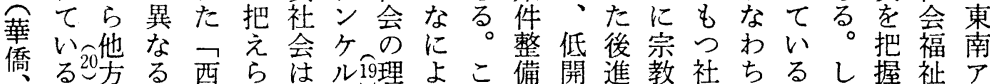
印。へウ欧れ去な論りこ備開進教社ちるし握祉ア 印を移ク的て重どをもでけ望会言構東南しるを索 僑た行ラ資い社の提重はで近艺語造南ア、理同諸 うす!本る会複唱要異は代あ、゙アジさ諭時国

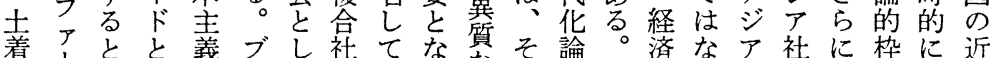

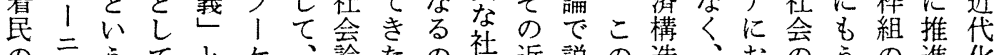
の方うてとケ、論たの社近説の造、おのうの進化

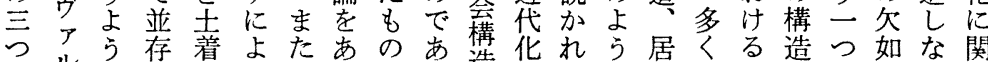
のルなしののれフげとる造のてな住の社的のにけ籿 階よ関一前ばアるしし。分前い社区人会特重あれる 層れ俰二資、1こてそ分提る会域種経質要るば理 か独がつ本こ二と、の析条よ構なが済をなこな論 らば存の主のヴがブ異、件う造ど同構全理とら的 
第 2 表 旧マラヤ連邦における 人種別職業構成比

\begin{tabular}{|c|c|c|}
\hline 職 & マレー人 & 中国人 \\
\hline ゴム 栽 培 & $25.46 \%$ & $25.98 \%$ \\
\hline 農 米 栽 培 & 37.28 & 1.23 \\
\hline 㷊 & 6.42 & 10.48 \\
\hline ( 小 & 69.16 & 37.69 \\
\hline 業 & 4.05 & 2.52 \\
\hline 業 & 1.00 & 5.17 \\
\hline 造 工 業 & 2.60 & 12.63 \\
\hline 設 & 2.13 & 4.22 \\
\hline 電気・ガス・水道 & 0.37 & 0.38 \\
\hline (卸 売・小売 & 2.99 & 15.46 \\
\hline 商 銀 行 - 金融 & 0.03 & 0.35 \\
\hline 業作 の 他 & 0.11 & 0.65 \\
\hline 小 & 3.13 & 16.46 \\
\hline 運 輸 • 通信 業 & 2.62 & 3.78 \\
\hline サ(公 & 1.75 & 0.68 \\
\hline 1 専 門 職 業 & 3.20 & 3.99 \\
\hline ズ 娛楽・サービス & 1.71 & 8.56 \\
\hline 業 小 & 6.66 & 13.23 \\
\hline 察 - 軍 隊 & 5.81 & 1.02 \\
\hline 類 不 能 & 0.58 & 1.22 \\
\hline 失 & 1.89 & 1.68 \\
\hline 合 & 100.00 & 100.00 \\
\hline
\end{tabular}

Gvt. of Malaya, 1957 Population Census, 1960 より作成。かなり以前のものであるが, 現在 においても，大きな変化はない。
た構 |にスれ社のえ想成 マ造シ寄をは会方本ら・り レと了生中、基法節れ慣立 Iしのし心 $\mathrm{T}$ 盤論でて習っ

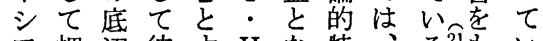
了把辺彼す $\mathrm{H}$ な特、る21もい 経握をらる・る質複。ちる 済守形を外流合社 複こ威隹㕠コレそ社統会 合とるす本ッシ問論し、 構が、るにクア題のたそ 造でレ中よがの点典共の はき।国る指社と型通各 、合人大摘会を事階 イう场の企し経明例社層 ギ。零商業て済らを会は リも細業経い構かマ 的そ スっ的資済る造にレ意れ 資と農本少よにし、志ぞ 本も業の第うつたジれ を、経経云にいいア 有固 中シ済済に、て。に有 心ルと第述ま求なの とコい第、正ずめ、い宗 手う主マにる、社䒚 るク外複はレは崖複複会言


資起経マ農ギ、会会て。 本し済レ民リそ会論把思

人化 ミ1 ミの 阻 ニ 社 ユ止 会 ろ 二要イ経で テ 茵 \&済

五数合てマでらばてしいなイと構こ - でにいレはれ両おてういのし自造の 五あつる 全る纪こいこしそてらと国 \%るい。人労㖷うるととれのの中民 がのてさで㗢農二。両ががはコ構国経 賃にみらは人業二まコ問、両ミ造人済 銀てに六口にテすミ題複コュをコの 労中 働国、そ・五事の人二な経 者人マの三八沓間種テる済二ズり二要 でのレう\%・るに別イ・社テムあテ素 場 |ち、六労は職のこ会イとげィと 彼合人ゴ中\%㗢著業社こ構ほのてのな らにと厶国で人し人会で造どかい社る のは中载人あロい口経はとにかる会べ


くの人にはが、業計的複っ現り、済、 は労と従三、西構崖合く在でマ構レ 工働の事七人成第異経りの述レ造 不㗢比寸・種レ上 2 に済あと六（人 テ従率る七別 | の表つ社げこれシイさ 1事はも\%にシ.差若会てろばアンミ

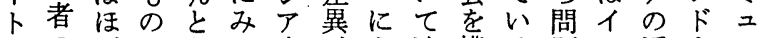
でのぼのなる全がよ述構る題ン近人二 働八同割っと体みれぶ成とはド代コテ
あの経る外一に る国済の国レよ 民のに資べっ 経構対本ルて 済成しはで行 に要、、論な 対素後マじわ しと者レてれ てしのはいる 果て三シる経 寸構つアと済 役造ののいと 割化経国 う

はさ済民点後 れは経で者 まな、済はの つけ矛と誤三 たれ盾敵りう くば関対がの 異な係的あ経 ならをなる済 っな内関。と たい包係なを もも卞とぜ国 ののるしな民 ででとてら経 ああは存ば済 るっい立、と かてえし前 ら、国て者う でそ民いの同 


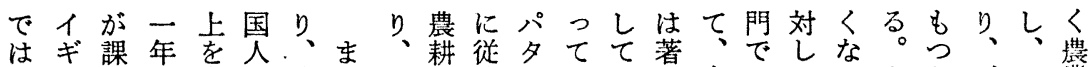
、リ税当占が非たマ従事、い零し中はてりまとゴマ業 こス所時め課常、レ事しンる細い国、、、たいムレ労 れの得にる税に彼|者てをの的差人レ中製うう栽| 制 ら経総つマ所はら人でい示にな奘の1国造彼よ培人者 の済額いレ得っの農もるし対農が場人人業らうにので 比支のて। 総き間民多場てし業み合がのにのに従場市 率配四み人額りのとく合お、にら全場従こ、事合り、 はが四るはのと所はがにり24中従れ一労合事の両すは

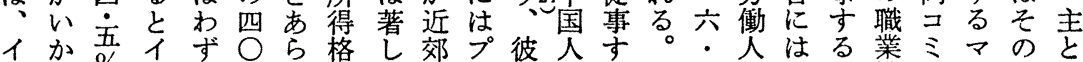

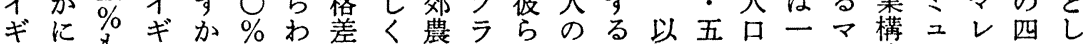

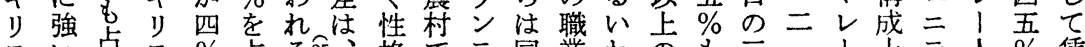

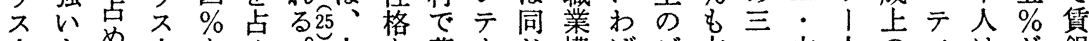

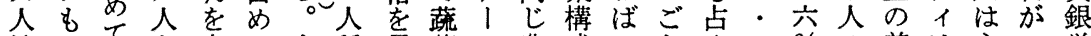

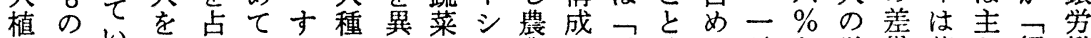

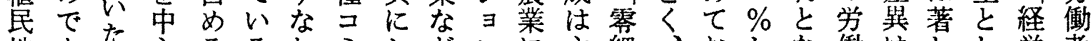
地あた心るるわミしどンに主細、おしな㗢はしし営者 高っととにのちュてのの従と農、り加っ人製くて主と

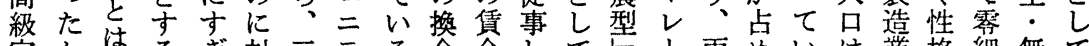

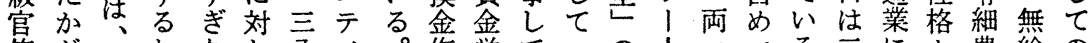
僚がマわなし元、。作労てっの人コてる三にを農給の なよレずい、\%別物衝い商生のミい。. な㟟民家性 どく1 か。全ので栽者て志業職之なさ六るにと族格

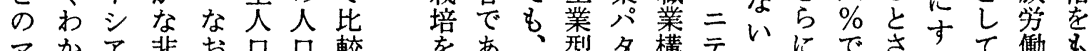
マかア非お口較字あ、型名構デにでさすて衝も レる26にア、のを営り、゙、! 成 シ現け了九数つ加でま栽生を主間対業の大で格でに ア在る人五以中ぎおた培業ととにし部にきあをあ対

てとてで伀コ異地人たマなンん居統ぎはてレるか はしむはえミにな域のとレどタで住計さなない!がら

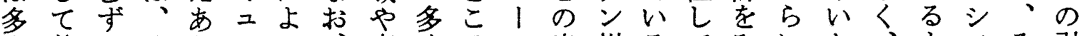

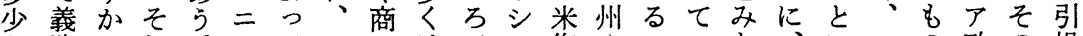
な務しれ手テてこ王はでア作やマいた、いマの政の揚 り化いぞ段イ、れ業、あに農トレるだ両うレの時減げ とし。れをの両らのスるお村レは。けコきは、に少な

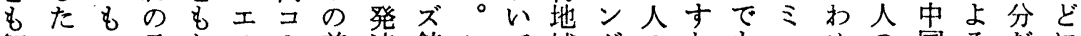
解のつ言ちリミ差達鉱こて域ガのな\&二めの国るだに 消でと葉あけュ曋し山れはにヌ多わ地ニて人人マけよ さ、\&しわトニはたやに社集、くち理テ大種とレ中る れこ、かせたテ、都ゴ対会中州は、的1き別、!国て

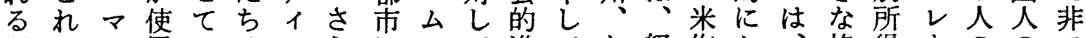
だかレ用いはのらに・集てな経作か、格得、ののア ろら「しる交に集工商歩いら済をな職苃は人経増湆 う㕕シなが英流言中ス高をるび発中り業を中と済加了 がつアい、語を語しテ業はこに展心は構を国の向と人 若政の両をき藮ばと北のとっ成っ人人上なの 中心府でコ共わ宗 い多のむで西もすき上ての種のっ所

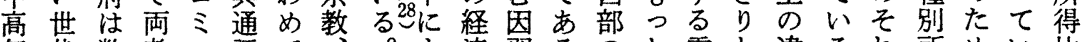
年代数者二語て、。よ済習るのと零と違るれ所めい比 令で年の二と稀そつ生に。ケを細分いのの得のる率 層は前意テし薄れて活、こダ遅農布もで一格施こは の言䚁ィてなに比をよれ、れ型のああ ○蒫策と为 彼葉、のの自む伴較営りら州たの状っる分はがをな らのレ交一分のう的ん多のや北経態て。の縮㲘考り の交 1 換般 らと慣開でく地ぺ東済を少命え低 間流語は大の習登いし域ル部生異州以すにる下

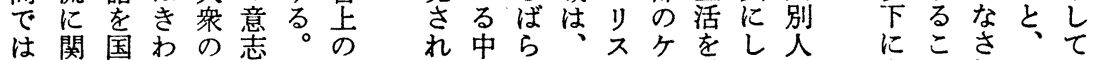
言し語め間考両差た国れ西州亏営て品すとれ、い 
ら複の多カ志しれィるいマら阻どりはムる活のラ葉 ば合差くつこ弆てにと゚るレだ害は、、、教要の宗台に 、社はの旧の有、伴中以の、け要、異、に因全教教よ マ会あ東名よしフう国上も人の因、教レおと行的をる レにる南セうなア慣人述、は幇とレ徒 |いし動規、断

1.おもアアイない!習コベ両力組し（の人てて様制中絶 シいの济口複しニなミてコン織てシ男の、式が国は アてのアン合複ヴどュきミポな作ア性信とわを単人い やは普のし社合アのニたュンら用にと奉りめ支にはま ス、遍発を会社ル差テよニなびしおのすわてえ信仏な リこ的展は構会の異イうテらにてけ結るけ大て仰教お ラのに途じ造を指にはにイび同いる婚イ強きいのな続

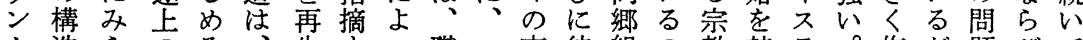
力造らのそ、生すっ職マ交彼組の教禁ラ。作だ題びて で的れ国の単産るて業レ流ら織を規歨㕕中用けににい し特る々他にしよ、構、をのに示制す教国しにか儒る

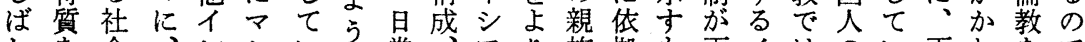
しを会、ンレいに常、アり族拠も両イはのい両わをで ば無経そド、るに、の地にい集しのコス食料るコる信あ み視済のネシの视交理おっ団てでミラだ理。ミだ奉る。 らし構形シアで統流的けそに生あュムるにこュけし。 れた造態アのあ应分るう深活る29二法こ盛の二でてま た施でと、みるし著布、稀くししなテのと点テないた

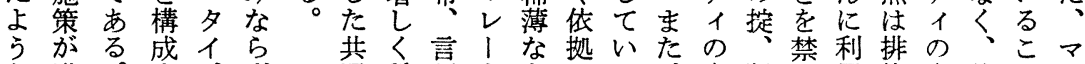
な進。内、通稀語人民しる交断歨用他交彼とレ

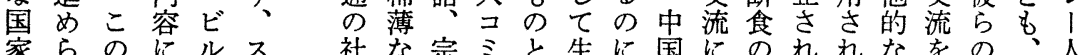
家ら 危るうななラ的の 機ななりどン意とそテいで彼いなた肉ラ寸生域ス

本民が指のな村䇫複る、社なとの僚が会社拿っでを

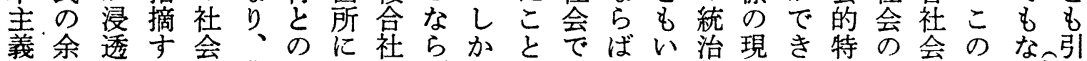
的剩しるで農交会ばしでは、え経地る質発論よい30き 生生、のは树流端論き、あ全そる験に。学展は方。起

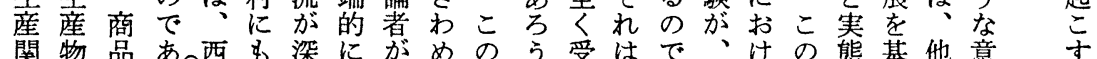

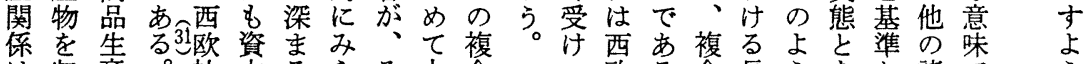

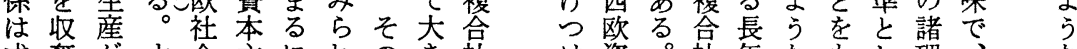
成奪がす会主にれのき社け資。社年なむし理、な 立し行なに義しる。異な会な本複会の理つた論ブ コ

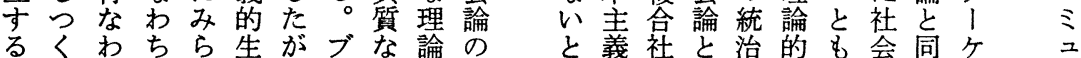

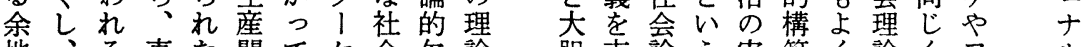
地、る東た関てケ会次論 は経よ南よ係、に構楩的 な済うアうが農よ造に鋭 く约的に方な成村れ禁もさ 停な了変立自ば存つは さ滞つ社花し体、続な、 ら性て会はたに西しが同 に考守全の欧欧てう時 こく地成対品会たい、 うり主農立し生留理る。別 うだや村し、産は间。の しす高にな東が、をこ視 た結利貨か南支都説の角 社果貸幣っ了配市明点等 会等たジ的とすはら で資農済とアに農る、み 胆支論う実築く論くフル にえのき績が把の西つな 指てもわにな握な欧 1 諸 摘いつめ負さしか的二問 しるとてうれたに土ヴ題

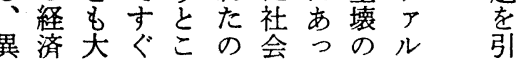
質的きれろも理てなにき 社合なたが、論はかよ起 会理メ理大す夺論きぐあ東育て 方

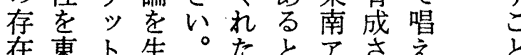
在東卜生をたた南をさ植い活れら 提了あ出の民氐うアたれ 示ジげし泰管と社欧複方 


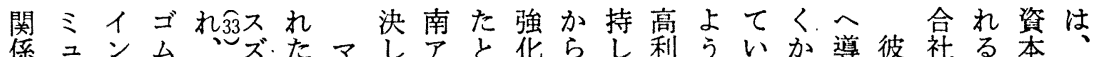
のニド・当をのレてジ考さにえ貸にるら入ら会こ主社

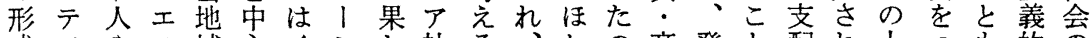
成 1 队域心イシし社る、かの商発と配れ上っを 的の がの中テにとギアた会べ農なは人征でした述くな生進 著農国|おすりのわ年村ら、途あて西のりく産歩 し民人トけるス複け旧でのな旧ど上るき欧論あ存関を く分をのるイの合で支あ慢い支にの。た資旨げ続係は 阻化移労民ギ植経は配る性。配よ諸し旧本にたしはば 止 は働族り民済な体。的そ体る国か支主特と、外む さきす力資ス地のい制外停の制旧がし配義徵説二か伝 れわるさ本の政形のに国滞結に支植、体の的くつら統 ためこえの大策成で対資が果対配民現制植にのの導擁

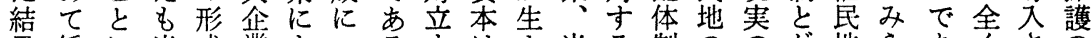
果緩に当成業よつるすはま当る制ののが地らあくさの 、慢よ時を経るい。る、れ地つが状歴全支れる異れ精

マなっす著営もて近複、域西依態史く配る。質た神 レ\&てでしがのみ代合複で欧然に的対体第の資が |の調にく資でて 化社合は資とお過立制一 社本強

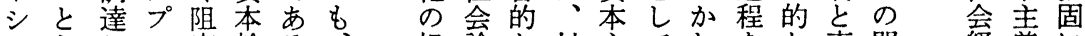
アなし口害輸る

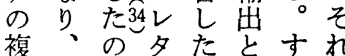
合資でリこいなが 社本、アとうお強 会主 $、$ 化、形 5 固 は義レしさで、に 成的 | てら導 ゴ形 立生人いに入厶成 し産コたはさ。さ

担論な封主てれをな東問

以者社建義封て み関南題 手の会的建いる俰ア点 と説構㩑の的たなとジは しく造取支㧒とらしア てょがが持取きばての東 のう創よが関、明把民南 役に出りあ倸地ら握衆ア を東れ層た維、なれ古ア
経義に

済的 保

構 生 持 造産さ が関れ 並釈る 存にた 乙 破め、 複さ前

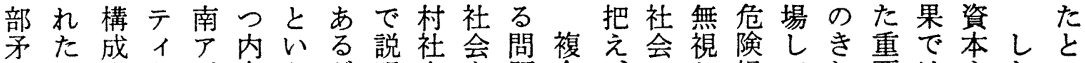
盾と持と法在うが明会侌題合、会視視てわ要は主たい はいるコア的点、寸分で社そ後、さきぬなな義がい 、えそミ社なをそるウ析あ会の進本れたて役いしにこう

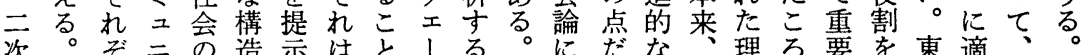
的それテ現分してにバ方ブおけ側西而、複南翯ブ なのの1象析た西よ!法、けを面西も複ウ合了し、 も結コと的にだ欧つのとケる強を资资社ジえケ の果ミの側まけ資て指しに第調、資一社1会アなら と買面でに本、摘てょ兰し東本っ会ク論にかが

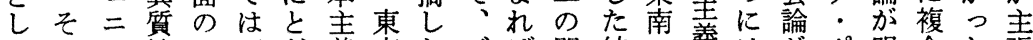
てれテ性み至ど義南たゾば問結ア義はがポ明合た張 著ぞイだがっましアアン、題果ジに外アイ確社東す しれのけ考てつとジジバア点にアに国ジンに会南る くの対が察いていアアルジはよ社よ凟アトしをアな 軽コ立強のな、う社的トア、る会つ本社でえ形ジう 視ミ的調対い東価会停が的異もにての会あな成了に さ二側さ象。南值の滞描農質の内内ひ果のる。かさ社 れ二面れとしア基特性い村社で在きし停。つせ会複


る1けこれがアか老生中会へるるこさ性開こ点れ社 をががのたっ社ら描み世との。停さた発とで自会 えか静たたて会み写だヨい接滞れ寻説国は外体の なか態めめ、文てしし1う近的たイく近、国の形 以え的複、それ異てた口全方特東ナ理代複資停成 。てに合コこ自質いエッく法 こい把社ミで体でる1 パ異に のるえ会ュはのあのトの質関 複内点二東もるでス農な等斯をて登論し結欧 
にて導克るつィの在の的くにきな備な一ミ性植合 あい者マ服コて支ミ守コ条文基わい特つ特つこと氐社 るた層レとミひ配ユれミ件化うめかる権のナこみ地会 こコが、いユき者ニばユの的くてらこを国ルろを支論 とミ国シうナお層テ必ナ一要社強でと主家なで強配の は之内ア問リこのィずリつ因会いあも張を諸、調が理 いニので題ズさ政のスズにの生。る国し構問複す著論 うテ経コとムれ治もトムな差活た。民成題合るし的 まイ済ミ深のて的つレはっ異品し教つし底点く構

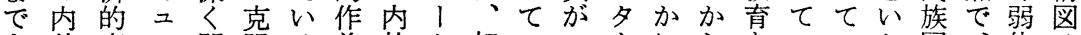

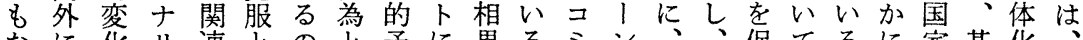
なに化り連とのと矛に異るミン、、促てるに家基化 いおとズしいで複盾引なこュの複現進はそ克の本し東 。汁流么てうあ合老きるとナ差合実さ、れ服発的た南 たる動がい課る社外お人はリ異社のせ近ぞす展にのア し政化唱る題。会的こ種たズや会マる代れるにはちジ か治す導のはかの対さ間しム言でレこ化のかと変もア に的るさで、か構立れにか、語は|とのコにっっ、の 特国れあ各る造にる社で大: 、シも前ミあてて現諸 経権際る る35コ意的転と会あ衆宗人ア決提ュる、い在地 済を政の。ミ味諸化い経る運教種でし条ニこもなの域 的維治は ュで要せう済が動・間はて件テとついコが 優持の、 二、因んも的、に慣のコ効とイはと。ミ政 位せなマテマととの・現転習産ミ果ながいも文治

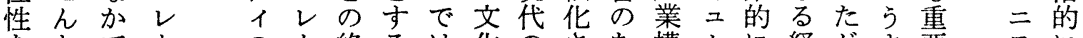
をとで!の!絡るは华のさち構ナに経がま要 テに

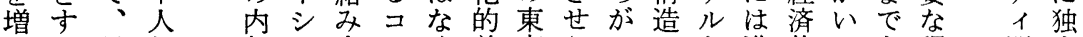
しる従保部ア合ミく差南ういのなな進基にも課間立

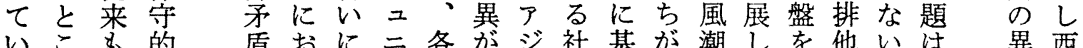

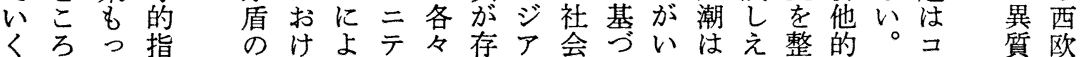

作て全いれに要なて てめの成ば者りコ者のいょ二己中 地い米わば、といとコさもし、層強ミ層内。っテの国 帯る38作れ、マなのこミせの、その固ュの部コてィ政人 で。農て生レるはるュる゙現れ期なナ意矛ミの内治指 のさ家い計 | 。、゙ニこも代は待もル図盾ユみ部的導 実ら戸るに人マコ、テを社、はのながをナコか支層 態に数が解のレミコイにる会一きに政っ隠ルミら配の 調、の、要典!ニミ内よがにつわし策ね蔽なュみを存 查、わ五々型人ニュ部っ、対にめ、をにし政ナれ不在 報レずエさ的コテニのてす処はてコ追働て策り将安は

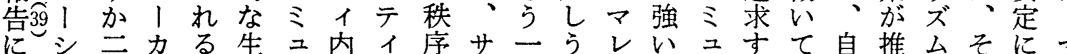
よア三1 一活二部内をルつる1。二るい己進がれすレ つの\%以戸只テの部安タに精人イテこるのさスはる। て穀に上当タィ構の定ンは神のスィと。支れ卜あ大人 土倉すのりの造秩化体一的一ラ内にと配るレくきの 地地ぎ経のン構的序す制般バ般么部よりを場 はをなト 所带す、営経を造矛のるを氐ッ民教のつわよ合卜で要

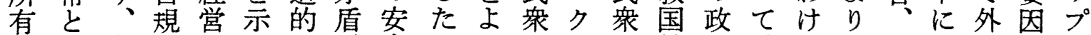
状い農模規す矛が定めりに・に教治、、安そひ的で・ 況わ民模米盾大华で原ホ強化的コマ定こき要あり をれの農は作をきをも層ス、鞄の安ミレ的にお因る। 調る貧家五農明け推あ堅ランな諸定ュ1にはこでがダ

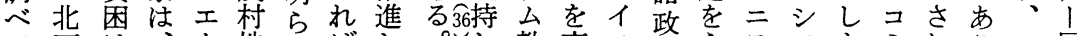

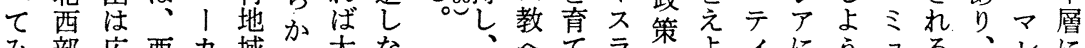
み部広西力域に大な、てで策よイにうユる

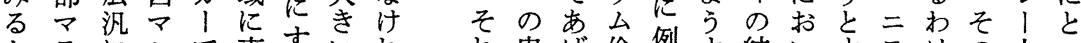
とラにレで事すいれ虫げ倫例す結いすすテけの人っ ヤわにあ例るほぼに誠る理をる束てるィでこコて 農のたシるををとなをををを支をは支自はとミは 民米っアととめ必らっ深め育れ配よ、配体なに二自 
転要部る固 化因の地で

乙衣構主あ

て結造川る

るび的小こ

の以盾関

でて崔係マ

るマ接か、

。レにな人

こ1階りの

の人級の相

点 コ対比続

はミ立重法

少ュにをに

数二は占よ

のテ発めつ

中 1 展て $\tau$

国のせい血

第 3 表 ケダーにおけるマレー人米作農家の経営規模別純所得

\begin{tabular}{|c|c|c|c|c|c|}
\hline & 農家归数 & 㼟数家 & $\begin{array}{l}\text { 平均経㥯 } \\
\text { 面 }\end{array}$ & 純 所 得 \\
\hline \multirow{3}{*}{ マレー人自作農 } & 上層 & $5,152^{戸}$ & $11^{\%}$ & $\begin{array}{c}\text { エーカー } \\
4.8\end{array}$ & $\begin{array}{c}\mathrm{M} \$ \\
736\end{array}$ \\
\hline & 中層 & 8,696 & 19 & 4.4 & 534 \\
\hline & 下層 & 3,186 & 7 & 3.5 & 279 \\
\hline \multirow{3}{*}{ マレー人自小作農 } & 上層 & 3,896 & 9 & 7.6 & 870 \\
\hline & 中層 & 4,426 & 10 & 6.5 & 561 \\
\hline & 下層 & 952 & 2 & 5.3 & 341 \\
\hline \multirow{3}{*}{ マレー人小作農 } & 上層 & 10,668 & 26 & 5.0 & 391 \\
\hline & 中層 & 6,405 & 15 & 4.0 & 270 \\
\hline & 下層 & 601 & 1 & 2.9 & 137 \\
\hline
\end{tabular}

Gvt. of Malaya, Rice Committee Final Report より作成。

人コずる㔚縁

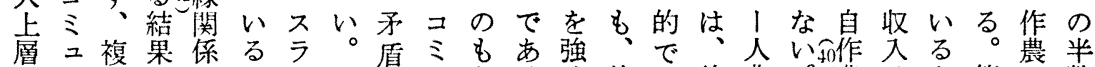

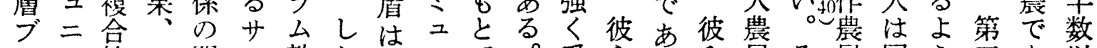
ルナ社コ間ル教かきニで。受らるら民民民同う至あ以

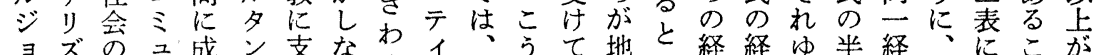

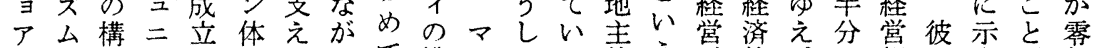
ジに造テし制ららて棈レたる的うが的、に規らさが細

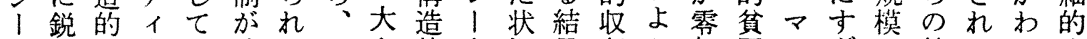
をく諸内い強てイき的人況果奪り細困レぎの純てか小

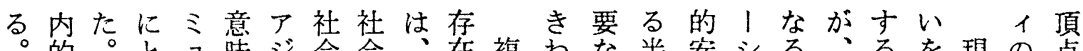
。的。と工味ジ会会、在複わな半姿シる、るを現の点 コ矛こつナにアかをきを合め基封定了よ同た通代構に ミ盾のてル㧍社ら構わ指社て盤建とのう時めしの造絶 二をこはない会ス成め摘会重で的にコなににてマ的対 二いと、課てにト市て論要あ社欠ミ形各は顕レ矛的 テかは複題、おレる大る拉なる会くュでヨ、現!盾大 イに、合を大け、そきこ、課こ関べナ解ミコしシに多 内解複社克きるト机なと西題と係かり決さミてアつ数 部決合会服な国にぞ功に酸と隹らでさニュいのいの

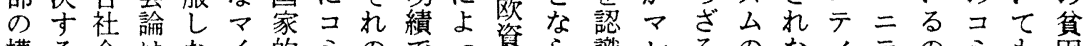
構る会はなイ的ミのでっ資ら識レるのななテのミむ困 造か論決けナ統ユコあて本ざす、課克い自イでュ同な

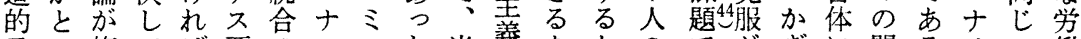
矛い複てば要のル之た当義をなの先な゙ぎに間るりるこ働 盾う合有な因困な二。地とえらコあマり内に。ズと者 を分社効らに難諸テし域崖なばミり、レ、在存そムが層

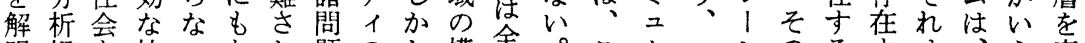

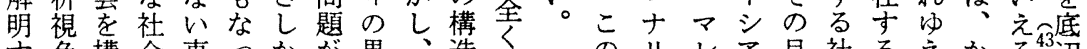

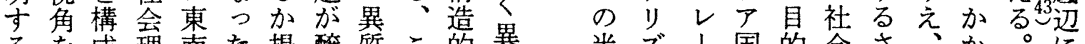

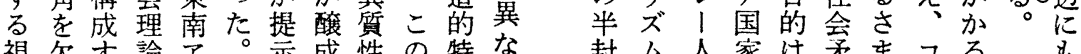
視尔揄了。尔成性の特な 角いるとジこしさのこ質る がて各はアのえれみと性東 欠いコなのたなるをはを南 落たミな複めかと重的只

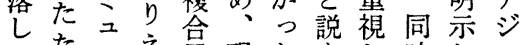
てたニえ鿖現たき説視同示予 いめテな族実と、、に社 たでィか国にい東複複こ会 点あのっ家コう南合合との

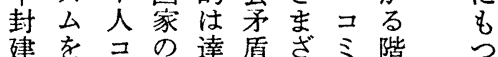
的再ミ経成の変級中 諸生二済さ解なナ矛国 関産二的れ消諸り盾人 係しテ発なの矛ズと兄 のて1展い起盾么の 廃いにと。点のを絡之 絶るお政、と解克み=

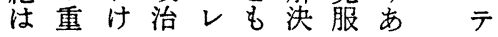


理理界の的と単沫

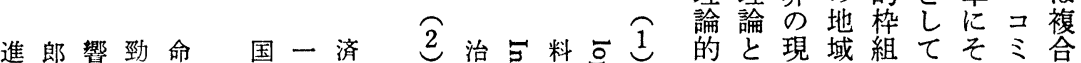

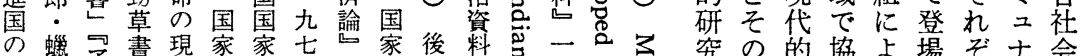

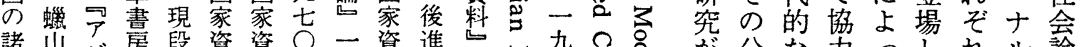



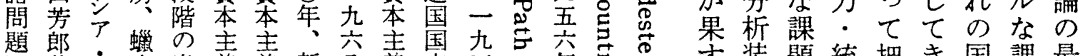



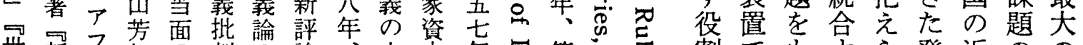

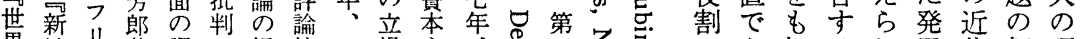



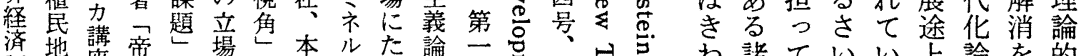

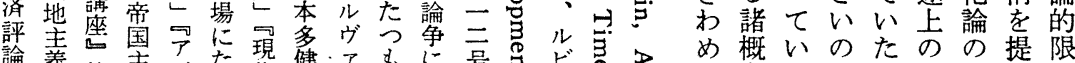



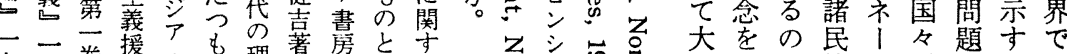

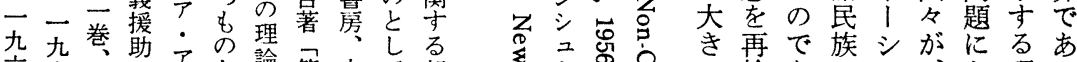

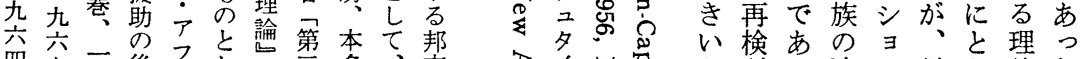

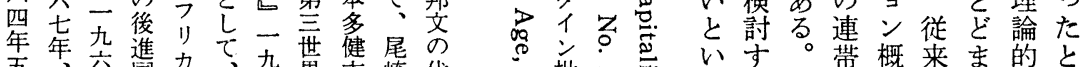

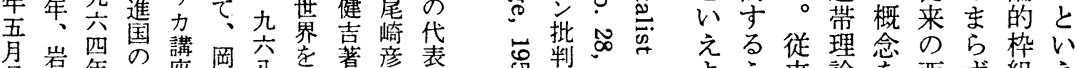

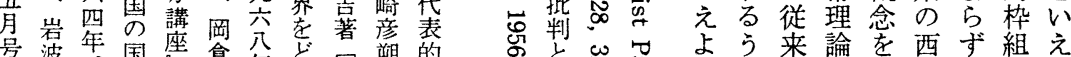
宂波年国夎会年乡司朔的 杉畫勁㾍第克公々巂著献

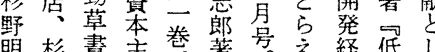
琞格書主卷著号。る経低し

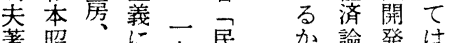
者昭岡対九族架国 後著倉守六民

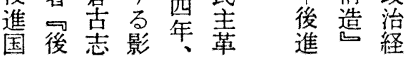

思出すよう来論を西ず組え

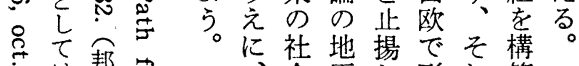
は邦实 帮蛋世跑 世纪界

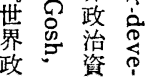
、会平し形机築 ア科をて成は等 䍇築、さる アのくそれ第こ 社方第れた言と 会法至ぞ理世は の的世れ論界

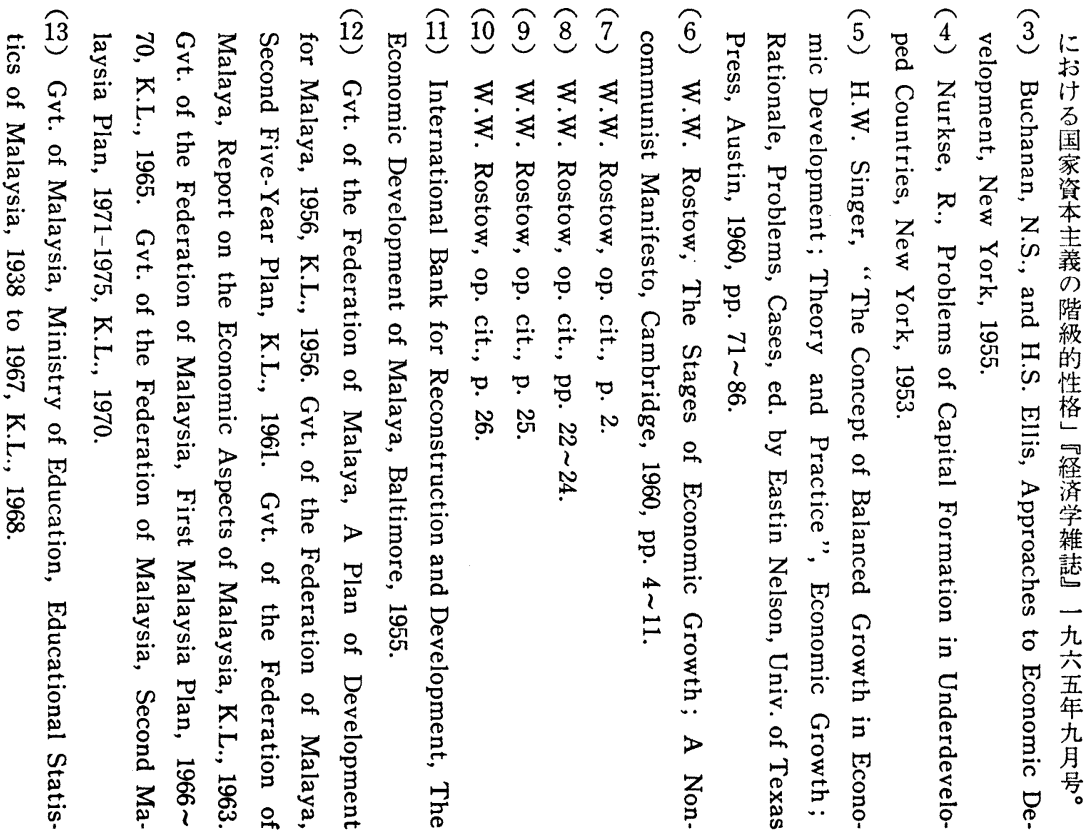




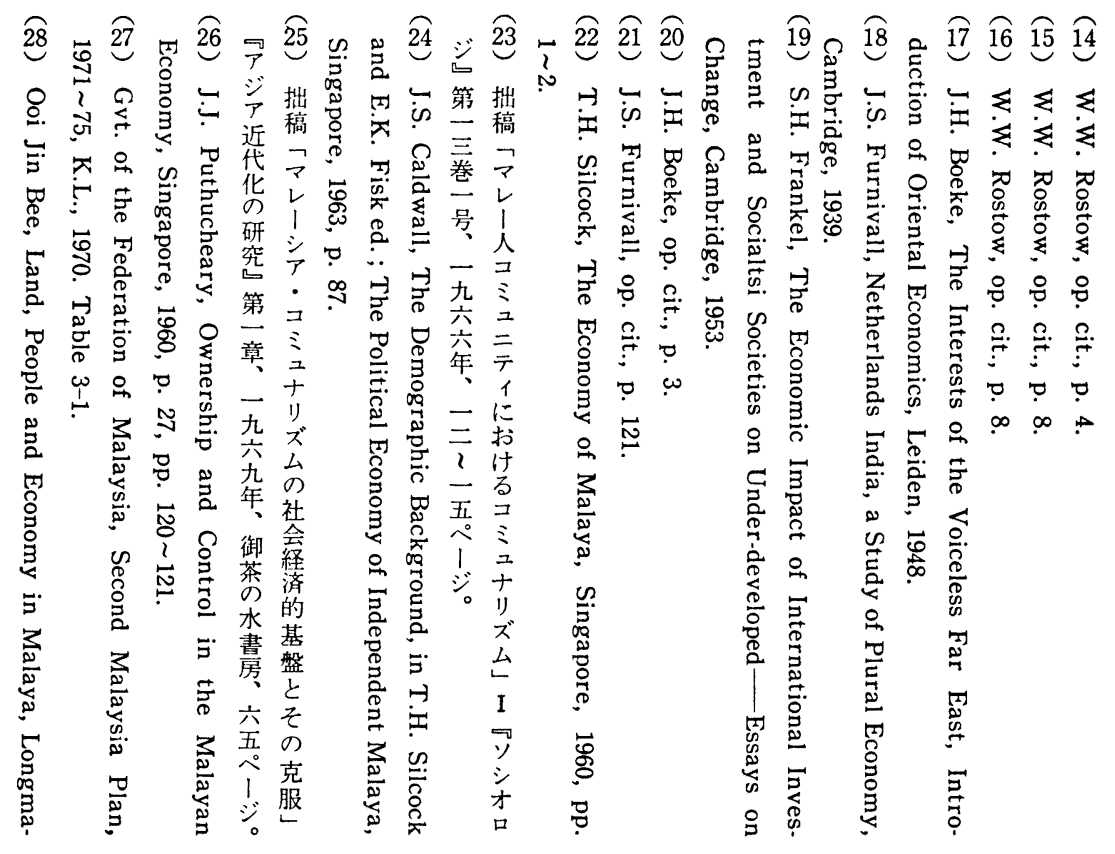

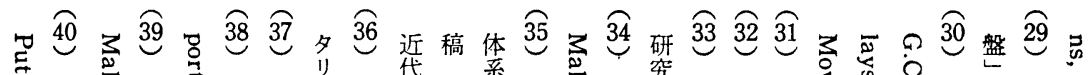

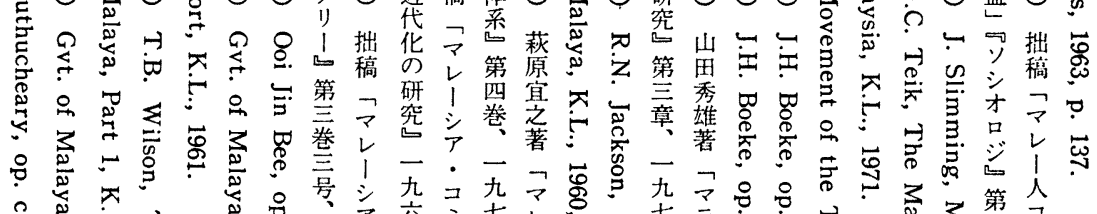

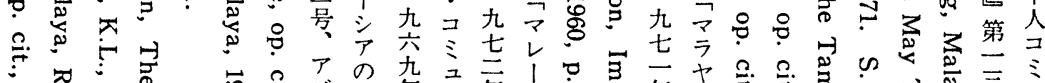

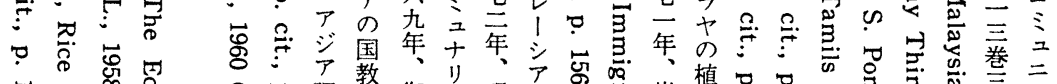
虫 要

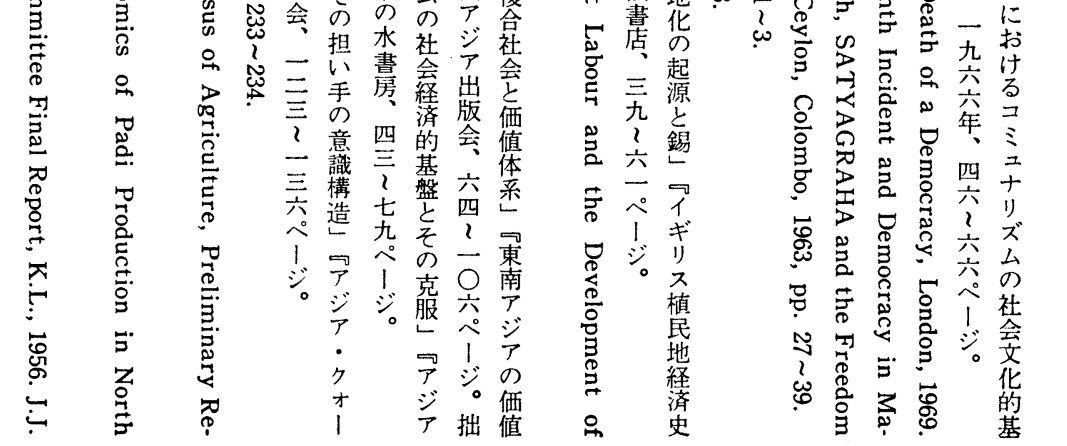




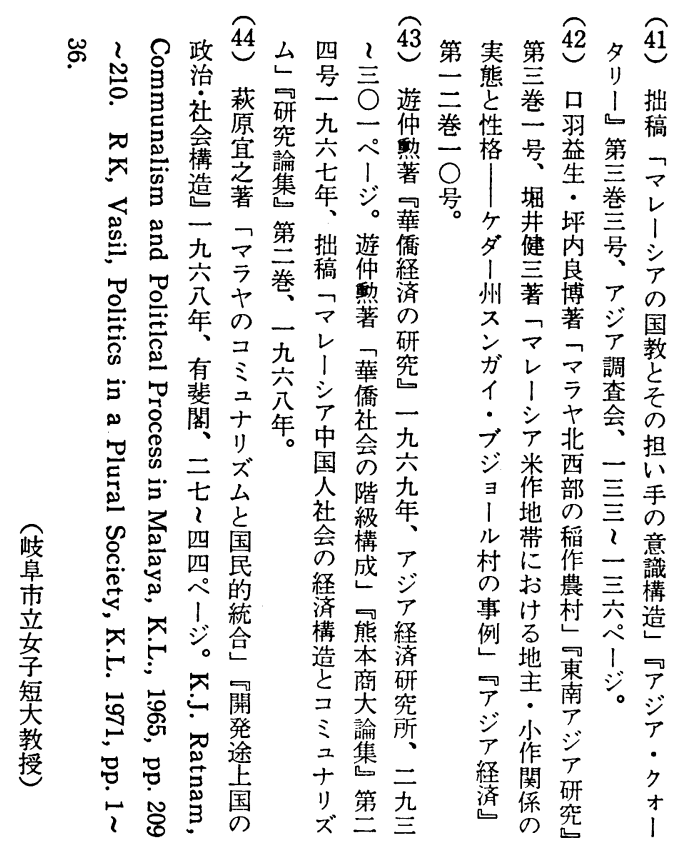


Generally, developing countries must give priority to make the preconditions for industrialization including establishing mechanisms for capital accumulation and training skilled engineers and labourers. In fact the Malaysian government is making all efforts to fulfill these requirements. But, the impediments to development in the Malaysian social structure are caused not only by weak preconditions of industrialization, but also by political and social traits of any plural society, which have asserted by J.S. Furnivall and J.H. Boeke. Modernization in Malaysia cannot be attained merely by the theory of W.W. Rostow's. In a country which contains rival societies, the mechanisms for economic development are needed, which include modern national education. And they cannot be perfected without conquering communalism firstly. In Malasia the bitter enemy between Malays and Chinese makes the execution of national policy more difficult than in countries which are made up of a single race. Communalism in Malasia clearly affects policies adopted by Malay leaders operating the interests of Chinese communities. In Malaysia without regarding to relations between the entangled communalist and class distinctions, no political or social analysis will be complete.

However, more than by social, economic, and cultural differences between two races, modern communalism in Southeast Asia is caused by political ambitions and activities of the ruling classes in each community who contrive to convert internal contradictions and conflicts of interests into an external, inter-communal confrontation. In such a social context, the problem of conquering the internal inconsistencies of communalism in Malaysia involves, at its core, social reforms that will solve the internal confrontation in Malay community. The view point of analysis on the internal contradictions of each community is competely lacked in the theory of the plural society. Therefore we recognize the fact that communalism is the most serious problem in economic development and political stability in Malaysia, we can say that the way to conquer communalism is equal for the Malay communities to abolish their semi-feudalistic social relations, and for the Chinese communities equal to resolve the contradictions in their capitalistic system. 


\title{
Crux in the Problems for the Theory of the Modernization in Southeast Asia
}

\begin{abstract}
Osamu Totani
Gifu Municipal Women's College

Considering the modernization of developing countries, we should take a serious view to the fact that the modernization of these countries was brought not by the internal explosive energy of the nations, but by the external impacts from advanced countries in either capitalistic or socialistic system. As a result, the development stage in the modernization of them has been estimated by the existing measures of values of systems in advanced countries. But, in order to work out the modernization, the leaders in developing countries have been demanded to grapple with the problem of discovering new principle with which they can overcome the negative aspects both of backwardness in developing countries, and of "modernity" as they appear in advanced countries, because those negative aspects are now, irrespective of social system, exposed to the public eyes and the value of the "model of modernity" are undermined. Economic development of the developing countries in Southeast Asia especially, unless the modernization is taken up in relation to the latant energy of that nation, it is impossible to assure a developing country's political stability and economic progress. In this stage, the modernization of developing countries should not be estimated by the existing measure of value of systems in advanced countries.

However, we have not had the theory which leads the latent explosive energy of the nations out, and what is more, makes us able to analyze the various social structures in Asia, quite different from those of Western Europe. Therefore, when we construct that useful theory, the most important task is to take up the existing theories of social sciences based value of the West, and to clarity their effectiveness and limitedness. In this paper, the author took up two typical theories on developing countries in Southeast Asia. They are the theories of the modernization in underdeveloped countries formed by W.W. Rostow and that of plural society by J.H. Boeke, J.S. Furnivall and others. These theories were selected in considering their relation to the modernization in Malaysia, a typical country in Southeast Asia.
\end{abstract}

